\title{
Activities of enzymes of the pancreas, and the lumen and mucosa of the small intestine in growing broiler cockerels fed on tannin-containing diets
}

\author{
BY A. E. AHMED, R. SMITHARD* AND M. ELLIS \\ Department of Agricultural Biochemistry and Nutrition, University of Newcastle upon Tyne, \\ Newcastle upon Tyne NEI 7RU
}

(Received 23 April 1990-Accepted 20 September 1990)

\begin{abstract}
Diets containing vegetable tannins, predominantly hydrolysable gallotannins, at levels of $13.5,25$ and $50 \mathrm{~g} / \mathrm{kg}$ were fed to growing broiler cockerels to examine their effect on enzymes in the pancreas, the intestinal lumen and the intestinal mucosa. Pancreas weight per unit live weight showed a significant $(P<0.05)$ increase with increasing level of dietary tannin while that of the liver remained unaffected. Trypsin $(E C 3.4 .21 .4)$ and $\alpha$-amylase $(E C 3.2 .1 .1)$ activities in the pancreas of birds fed at the highest level of tannins were more than double those from birds fed on a tannin-free control diet. In the intestinal lumen inhibition of trypsin activity increased with increasing level of dietary tannin; $\alpha$-amylase activity was inhibited at intermediate tannin levels but was restored at the highest level. Dipeptidase (EC 3.4 13.11) and sucrose $\alpha$-glucosidase (disaccharidase) $(E C$ 3.2.1 .48) in the intestinal mucosa were both inhibited by tannins. Growth of the birds and digestibility of nitrogen were adversely affected by the tannin-containing diets.
\end{abstract}

Tannin: Pancreatic enzymes: Brush border enzymes: Cockerel

It is well established that tannins are potential protein precipitants (Hagerman \& Butler, 1980; Hagerman \& Klucher, 1986; Makker et al. 1987) and that they reduce the digestibilities of proteins (Mohammed \& Ahmed, 1987) when present in animal feeds. Elevated faecal nitrogen excretion associated with ingestion of tannin-containing feeds is ascribed largely to interactions between either tannins and dietary protein or tannins and digestive enzymes, or both. However, Mitjavilla et al. (1977) concluded that the excess faecal $\mathrm{N}$ is mostly a result of mucus hypersecretion.

Studies in vitro (Griffiths, 1981 ; Lumen \& Salamat, 1980; Horigome et al. 1988) and in vivo (Griffiths \& Moseley, 1980; Horigome et al. 1988) have demonstrated the formation of tannin-enzyme complexes. However, adopting a technique in vitro more relevant to the situation in vivo, Mole \& Waterman (1987) showed that trypsin retained all its activity in the presence of tannic acid when the system included a substrate protein (bovine serum albumin; BSA) and glycocholic acid, indicating that under such conditions tannins have a preferential affinity for dietary protein over enzyme protein. In previous work Mole \& Waterman (1985) had shown that the formation of complexes between tannins and BSA, used as a substrate for proteolysis, could result in either enhancement or inhibition of proteolysis, or no effect at all depending on the tannin:BSA ratio in the complex.

In contrast to what had been reported with rats (Griffiths \& Moseley, 1980; Horigome et al. 1988), tannins were shown to exert no effect on protein digestion by insect herbivores (Martin et al. 1985, 1987).

The present study was undertaken to investigate the response of the pancreas to tannins

* For reprints. 
Table 1. Ingredients and chemical composition of experimental diets

\begin{tabular}{|c|c|c|c|c|}
\hline \multirow[b]{2}{*}{ Total tannins* $(\mathrm{g} / \mathrm{kg}) \ldots$} & \multicolumn{4}{|c|}{ Diet } \\
\hline & $50 \cdot 0$ & $25 \cdot 0$ & $13 \cdot 5$ & 0.0 \\
\hline \multicolumn{5}{|l|}{ Ingredients $(\mathrm{g} / \mathrm{kg})$} \\
\hline Barley & - & $280 \cdot 0$ & $410 \cdot 0$ & $557 \cdot 5$ \\
\hline Salseed meal & 5160 & $257 \cdot 0$ & $137 \cdot 0$ & - \\
\hline Soya-bean meal & $255 \cdot 0$ & $247 \cdot 5$ & $245 \cdot 0$ & $240 \cdot 0$ \\
\hline Rice & $120 \cdot 0$ & $120 \cdot 0$ & $120 \cdot 0$ & $120 \cdot 0$ \\
\hline Wheat bran & $50 \cdot 0$ & $50 \cdot 0$ & $50 \cdot 0$ & $50 \cdot 0$ \\
\hline Fish meal & $41 \cdot 0$ & $33 \cdot 0$ & $28 \cdot 0$ & $25 \cdot 0$ \\
\hline Vegetable oil & $18 \cdot 0$ & $12 \cdot 5$ & $10 \cdot 0$ & $07 \cdot 5$ \\
\hline \multicolumn{5}{|l|}{ Composition } \\
\hline Crude protein (nitrogen $\times 6.25 ; \mathrm{g} / \mathrm{kg}$ ) & $201 \cdot 5$ & $201 \cdot 5$ & $201 \cdot 2$ & $20 ! \cdot 4$ \\
\hline Metabolizable energy $(\mathrm{MJ} / \mathrm{kg})$ & $12 \cdot 66$ & $12 \cdot 64$ & $12 \cdot 60$ & 12.64 \\
\hline
\end{tabular}

* Estimated from condensed and hydrolysable tannin content of salseed meal.

in terms of changes in activities of enzymes in the lumen of the small intestine, in order to provide further insight into the mode of action of dietary tannins. A further aim was to examine the effect of dietary tannins on the activity of membrane-bound enzymes which are considered to take part in nutrient absorption (Miller \& Grane, 1961).

In a series of experiments, extracted meal from the seed of the Sal tree (Shorea robusta) was used as a source of tannins. The seed is mainly collected from tropical forests for its oil. The seed residues after oil extraction have a crude protein (nitrogen $\times 6.25 ; \mathrm{CP}$ ) and a carbohydrate content similar to that of cereals but have a much higher content of tannins, particularly hydrolysable tannins.

\section{MATERIALS AND METHODS \\ Experimental animals and diets}

The broiler cockerels ( $C o b b)$, supplied by Hamish Morison Ltd, Earlston, used in the present experiment were received on the day of hatching. They were reared in a group for 2 weeks on a commercial broiler starter mash (Varley Feeds, Darlington). Rearing and experimental treatments were conducted in a controlled environment room (temperature $22 \pm 2^{\circ}$, lighting period $23 \mathrm{~h} / \mathrm{d}$ ).

The formulation and estimated chemical composition of four isonitrogenous $(20 \mathrm{~g} \mathrm{CP} / \mathrm{kg})$ and isoenergetic $(12.6 \mathrm{MJ} / \mathrm{kg})$ diets containing salseed meal (diet 1), barley (diet 4) or mixtures of salseed and barley (diets 2 and 3 ) are shown in Table 1. Vitamin-mineral premix (Nutec Ltd, Lichfield) was added to the feed at a rate of $25 \mathrm{~g} / \mathrm{kg}$. The estimated composition is based on analysis of the components used in the preparation of the diets.

\section{Analysis of tannins}

The vanillin method of Price et al. (1978) was used to estimate the content of condensed tannins which were extractable only in acidified methanol $(10 \mathrm{ml}$ hydrochloric acid $/ \mathrm{l})$. The vanillin reagent gives positive reactions with non-tannin free flavanoids (Sarker \& Howarth, 1976). Polyvinylpyrrolidone was used to bind tannins and, thereby, provide a blank which compensated for the contribution of the non-tannin free flavanoids to the colour development with the vanillin reagent. The dye-labelled protein precipitation 
method (Asquith \& Butler, 1985) for total tannin content was applied to extracts made with aqueous methanol $(500 \mathrm{ml} / \mathrm{l})$. Since the condensed tannins were not extracted with this solvent the result was taken to be the content of hydrolysable tannins.

\section{Digestibility trial}

After the adaptation period, birds were weighed and allocated to forty individual battery cages. Each cage was equipped with a feeding trough, a drinker and a tray for the collection of excreta. Each of the four experimental diets were fed to ten birds. Throughout the experiment diets were moistened just before feed was offered to minimize losses of feed and marker. Experimental diets to which chromic oxide $(20 \mathrm{~g} / \mathrm{kg})$ had been added were fed for the $15 \mathrm{~d}$. Feeding was restricted $(65 \mathrm{~g} / \mathrm{d}$ at start, rising to $95 \mathrm{~g} / \mathrm{d}$ on day 15$)$ so that all birds, irrespective of diet, consumed the same amount of feed each day. No collections of excreta were made for the first $7 \mathrm{~d}$ in which the passage of $\mathrm{Cr}_{2} \mathrm{O}_{3}$ was allowed to stabilize (Kotb \& Luckly, 1972); collection of excreta was started after day 7. Some birds (two birds per treatment) were fed on experimental diets without $\mathrm{Cr}_{2} \mathrm{O}_{3}$ to provide gut tissue samples for histological examination and to provide sample blanks for use in $\mathrm{Cr}_{2} \mathrm{O}_{3}$ analysis. Collection of excreta was carried out at least six times each day over a $7 \mathrm{~d}$ period; collected excreta were immediately frozen, subsequently freeze-dried, ground and stored at $-4^{\circ}$ in sealed plastic containers while awaiting analysis. Excreta samples were analysed for total $\mathrm{N}, \mathrm{Cr}_{2} \mathrm{O}_{3}$ (Fenton \& Fenton, 1979), uric acid (Terpstra \& De Hart, 1974) and ammonia (Agricultural Development and Advisory Service, 1986). N digestibility was calculated by the method of Terpstra \& De Hart (1974). After the digestibility trial, birds were kept on the same diets but without $\mathrm{Cr}_{2} \mathrm{O}_{3}$ for a further 2 weeks during which feeding was ad lib.

\section{Sample collection for determination of enzyme activities}

After 4 weeks on the experimental diets the birds were killed by cervical dislocation. The digestive tract was promptly exposed and each segment was tied to prevent further movement of the gut contents. The distal duodenum was removed and carefully washed with ice-cold saline ( 9 g sodium chloride/1). The contents of a length (about $150 \mathrm{~mm}$ ) of jejunum were extruded by gentle pressure between the thumb and forefinger into a preweighed specimen tube and stored at $-20^{\circ}$. The pancreas was also removed, freed from connective tissue and fat, frozen in liquid $\mathrm{N}_{2}$ and stored at $-70^{\circ}$.

\section{Preparation of tissue homogenates and determination of enzyme activities}

The duodenal sections were cut open longitudinally, laid on the base of an ice-cooled Pyrex oven dish and the mucosa was scraped off using a microscope slide. The weighed mucosa was homogenized in ice-cold distilled water (Lasheras et al. 1980), centrifuged (15200 $\mathrm{g}$ for $20 \mathrm{~min}$ at $5^{\circ}$ ), diluted with distilled water and analysed immediately for dipeptidase (EC 3.4.13.11; Nicholson \& Kim, 1975) and sucrose $\alpha$-glucosidase (disaccharidase) (EC 3.2.1.48; Dahlqvist, 1968) activities.

Portions of intestinal chyme $(1-1.5 \mathrm{~g})$ were homogenized in ice-cold saline and centrifuged $\left(70000 \mathrm{~g}\right.$ for $20 \mathrm{~min}$ at $\left.4^{\circ}\right)$. After dilution the supernatant fractions were assayed for trypsin (EC 3.4.21.4) (Hamerstrand et al. 1981) and for $\alpha$-amylase (EC 3.2.1.1); dye-labelled starch (Starch Azure; Sigma) was used as the $\alpha$-amylase substrate.

Each pancreas was homogenized in potassium chloride $(0 \cdot 154 \mathrm{~mol} / \mathrm{l})$-Tris- $\mathrm{HCl}$ $(50 \mathrm{mmol} / \mathrm{l})$, adjusted to $\mathrm{pH} 7.4$ and centrifuged $\left(70000 \mathrm{~g}\right.$ for $20 \mathrm{~min}$ at $4^{\circ}$ ). Trypsin and $\alpha$-amylase activities were determined as described previously; pancreatic trypsin was activated using purified enteropeptidase (enterokinase) (EC 3.4.21.9; Gertler \& Nitsan, 1970). 
Table 2. Live-weight gain (age 14-42 d), feed conversion efficiency (age 28-35d), apparent nitrogen digestibility (age 21-38d), and liver and pancreas weights (age $42 d$ ) in fowl fed on diets containing different levels of tannins

\begin{tabular}{l} 
(Results are means with their standard errors for eight animals) \\
\cline { 2 - 7 } \\
Total tannins (g/kg)...
\end{tabular}

a. b.u, d Values in the same row with different superscript letters were significantly different $(P<0 \cdot 05)$.

* For details, see p. 190 and Table 1.

\section{Statistical procedure}

Results were subjected to analysis of variance to detect differences between treatments. Means were then compared using Duncan's multiple range test.

\section{RESULTS}

\section{Tannin content of salseed meal}

The condensed tannins of salseed meal were present at a level of $26 \mathrm{~g}$ catechin equivalent (CE) $/ \mathrm{kg}$ and the hydrolysable tannin content was estimated to be $73 \mathrm{~g} / \mathrm{kg}$.

\section{Animal performance and protein digestibility}

All performance variables presented in Table 2 were adversely affected $(P<0.05)$ by increasing levels of dietary tannins. Birds which received tannins in their diets at levels of $13.5,25.0$ and $50.0 \mathrm{~g} / \mathrm{kg}$ achieved live-weight gains of $0.82-, 0.63-$ and 0.27 -fold those achieved by the birds fed on the tannin-free diet between weeks 1 and 4 of the treatment period. This effect amounted to a decrease in live-weight gain of between 197 and $234 \mathrm{~g}$ for every $10 \mathrm{~g} / \mathrm{kg}$ increase in tannin content of the diet. Feed conversion efficiency, recorded in week 3 , of birds which received the highest amount of tannins was reduced by more than half compared with the controls. Apparent digestibility of protein was negatively correlated with tannin content $(\mathrm{g} / \mathrm{kg})$ of the diet (digestibility $=0.79-0.0076 \times \operatorname{tannin}$ content, $R^{2}$ $0.91, n 32$ ). The effect on protein digestibility, of tannins at the highest level, was disproportionately greater than at the lower levels.

\section{Pancreas and liver weights}

Tannins exerted a significant $(P<0.05)$ effect on the weight $(\mathrm{g} / \mathrm{kg}$ live weight) of the pancreas but the liver weight remained unaffected. No lesions were observed in either the pancreas or the liver. The weight of the pancreas from birds which received the highest amount of tannins was more than twice that of the control birds. Significant enlargement of the pancreas was detectable only at tannin concentrations above $13.5 \mathrm{~g} / \mathrm{kg}$. As the tannin 
Table 3. Trypsin (EC 3.4.21.4) activity (units $\times 10^{-2}$ ) and $\alpha$-amylase (EC 3.2.1.1) activity (units $\times 10^{-3}$ ) in pancreas of fowl fed on diets containing different levels of tannins

(Results are means with their standard errors of samples from eight animals)

\begin{tabular}{|c|c|c|c|c|c|c|c|c|}
\hline \multirow{3}{*}{ Total tanins $(\mathrm{g} / \mathrm{kg}) \ldots$} & \multicolumn{8}{|c|}{ Diet* } \\
\hline & \multicolumn{2}{|c|}{$50 \cdot 0$} & \multicolumn{2}{|c|}{$25 \cdot 0$} & \multicolumn{2}{|c|}{$13 \cdot 5$} & \multicolumn{2}{|c|}{0.0} \\
\hline & Mean & $\mathrm{SE}$ & Mean & $\mathrm{SE}$ & Mean & $\mathrm{SE}$ & Mean & $\mathrm{SE}$ \\
\hline \multicolumn{9}{|l|}{ Trypsin } \\
\hline Units/g pancreatic tissue & $124^{\mathrm{a}}$ & 13 & $98^{\mathrm{a}}$ & 8 & $106^{\mathrm{a}}$ & 11 & $109^{\mathrm{a}}$ & 11 \\
\hline Units/kg body-wt & $428^{a}$ & 66 & $255^{\mathrm{b}}$ & 28 & $249^{\mathrm{b}}$ & 29 & $206^{\mathrm{b}}$ & 17 \\
\hline \multicolumn{9}{|l|}{$\alpha$-Amylase } \\
\hline Units/g pancreatic tissue & $1165^{\mathrm{a}}$ & 119 & $1166^{\mathrm{a}}$ & 156 & $937^{\mathrm{a}}$ & 27 & $855^{\mathrm{a}}$ & 84 \\
\hline Units/kg body-wt & $3840^{\mathrm{a}}$ & 270 & $2740^{\mathrm{b}}$ & 200 & $2340^{\mathrm{b}}$ & 200 & $1620^{\circ}$ & 120 \\
\hline
\end{tabular}

a. b, c Values in the same row with different superscript letters were significantly different $(P<0 \cdot 05)$.

* For details, see p. 190 and Table 1.

content increased from 13.5 to $25 \mathrm{~g} / \mathrm{kg}$ and from 25 to $50 \mathrm{~g} / \mathrm{kg}$ the pancreas increased in weight by 33 and $110 \%$ respectively compared with the control birds. The effect of tannin content on pancreatic hypertrophy, like the effect on protein digestion, was disproportionately greater at the highest tannin level.

\section{Pancreatic enzyme activities}

When trypsin and $\alpha$-amylase activities (Table 3) were expressed as units per $g$ pancreas fresh weight there was no significant difference between treatments, although there was a trend towards increasing $\alpha$-amylase activity with increasing content of tannin in the diet. When these activities were related to live weight, significant differences were found. The pancreas from birds which received the highest amounts of tannins accumulated $1 \cdot 1$-fold more trypsin activity and $1 \cdot 4$-fold more $\alpha$-amylase activity than that observed in the pancreas from the control birds.

\section{Lumen enzyme activities}

The activities of both trypsin and $\alpha$-amylase in the gut (Table 4) suffered increasing inhibition as the level of salseed tannins in the diet increased from 0 to $25 \mathrm{~g} / \mathrm{kg}$. However, at the highest level $(50 \mathrm{~g} / \mathrm{kg})$, whilst the trypsin activity was lowest, the $\alpha$-amylase activity had been restored to a level near that of the control birds.

\section{Membrane-bound enzyme activities}

The activities (Table 5) of mucosal dipeptidase (L-leucylglycine substrate) and sucrose $\alpha$ glucosidase were both sensitive to tannins. At the highest level of tannins the activities of both enzymes were reduced to about one-third of that found in the control birds.

\section{DISCUSSION}

The differences in growth rate observed in the present experiment were consistent with previous observations on diets containing tannins (Mohammed \& Ahmed, 1987). However, in the later stage of the ad lib. feeding period a rapid increase in the growth rate was noted among the birds fed on the diets containing 50 and $0 \mathrm{~g}$ tannins $/ \mathrm{kg}$ but not in the birds on the other treatments. It is possible that this was a consequence of the restriction on feeding 
Table 4. Lumen enzyme activity in the mid-gut of fowl fed on diets containing different levels of tannins

(Results are means with their standard errors of samples from eight animals)

\begin{tabular}{|c|c|c|c|c|c|c|c|c|}
\hline \multirow{3}{*}{ Total tannins $(\mathrm{g} / \mathrm{kg}) \ldots$} & \multicolumn{8}{|c|}{ Diet* } \\
\hline & \multicolumn{2}{|c|}{$50 \cdot 0$} & \multicolumn{2}{|c|}{$25 \cdot 0$} & \multicolumn{2}{|c|}{$13 \cdot 5$} & \multicolumn{2}{|c|}{0.0} \\
\hline & Mean & $\mathrm{SE}$ & Mean & $\mathrm{SE}$ & Mean & $\mathrm{SE}$ & Mean & $\mathrm{SE}$ \\
\hline \multicolumn{9}{|l|}{$\begin{array}{l}\text { Trypsin }(E C 3.4 .21 .4 ; \\
\left.\text { Units } \times 10^{-2}\right)\end{array}$} \\
\hline /g wet chyme & $6.42^{\mathrm{a}}$ & $0 \cdot 30$ & $9 \cdot 12^{\mathrm{a}}$ & 0.76 & $14 \cdot 14^{b}$ & 1.44 & $24 \cdot 78^{c}$ & $2 \cdot 53$ \\
\hline /g dry chyme & $47 \cdot 42^{\mathrm{a}}$ & $5 \cdot 26$ & $60 \cdot 67^{a}$ & $5 \cdot 93$ & $102 \cdot 71^{\mathrm{b}}$ & $13 \cdot 24$ & $245 \cdot 20^{c}$ & $17 \cdot 27$ \\
\hline \multicolumn{9}{|l|}{$\begin{array}{l}\alpha \text {-Amylase }(E C \text { 3.2.1.1; } \\
\left.\quad \text { Unjts } \times 10^{-2}\right)\end{array}$} \\
\hline /g wet chyme & $66 \cdot 71^{\mathrm{a}}$ & 4.69 & $34 \cdot 60^{11}$ & 1.85 & $61 \cdot 46^{a}$ & 4.53 & $66 \cdot 64^{a}$ & $2 \cdot 50$ \\
\hline /g dry chyme & $454 \cdot 62^{\mathrm{a}}$ & $19 \cdot 79$ & $238 \cdot 60^{\mathrm{h}}$ & $17 \cdot 00$ & $435 \cdot 43^{a}$ & $27 \cdot 33$ & $603 \cdot 83^{c}$ & $49 \cdot 98$ \\
\hline
\end{tabular}

a, b, $c$, Values in the same row with different superscript letters were significantly different $(P<0 \cdot 05)$

* For details, see p. 190 and Table 1.

Table 5. Membrane enzyme activity in distal duodenal mucosa of fowl fed on diets containing different levels of tannins

(Results are means with their standard errors of sampies from eight animals)

\begin{tabular}{|c|c|c|c|c|c|c|c|c|}
\hline \multirow{3}{*}{ Total tannins $(\mathrm{g} / \mathrm{kg}) \ldots$} & \multicolumn{8}{|c|}{ Diet* } \\
\hline & \multicolumn{2}{|c|}{$50 \cdot 0$} & \multicolumn{2}{|c|}{$25 \cdot 0$} & \multicolumn{2}{|c|}{$13 \cdot 5$} & \multicolumn{2}{|c|}{$0 \cdot 0$} \\
\hline & Mean & $\mathrm{SE}$ & Mean & $\mathrm{SE}$ & Mean & SE & Mean & $\mathrm{SE}$ \\
\hline \multicolumn{9}{|l|}{$\begin{array}{l}\text { Dipeptidase } \\
\quad(E C 3.4 .13 .11 ; \\
\left.\text { Units } \times 10^{-3}\right)\end{array}$} \\
\hline /g mucosa & $1.55^{\mathrm{a}}$ & 0.23 & $2 \cdot 40^{b}$ & $0 \cdot 28$ & $2 \cdot 91^{b}$ & 0.26 & $4 \cdot 50^{\circ}$ & $0 \cdot 12$ \\
\hline /g protein & $43 \cdot 3^{a}$ & $7 \cdot 0$ & $73 \cdot 5^{b}$ & $8 \cdot 6$ & $92 \cdot 6^{b}$ & $10 \cdot 00$ & $139 \cdot 2^{\circ}$ & $10 \cdot 0$ \\
\hline \multicolumn{9}{|l|}{$\begin{array}{l}\text { Sucrose } \alpha \text {-glucosidase } \\
\quad(E C 3.2 .1 .48 ; \text { Units })\end{array}$} \\
\hline /g mucosa & $12 \cdot 6^{\mathrm{a}}$ & $1 \cdot 0$ & $13 \cdot 2^{\mathrm{a}}$ & 1.6 & $25 \cdot 7^{b}$ & 3.4 & $42 \cdot 4^{\prime \prime}$ & 1.7 \\
\hline /g protein & $347^{\mathrm{a}}$ & 37 & $397^{\mathrm{a}}$ & $5 \cdot 3$ & $620^{\mathrm{b}}$ & 47 & $778^{\mathrm{c}}$ & 37 \\
\hline
\end{tabular}

a. b.c Values in the same row with different superscript letters were significantly different $(P<0 \cdot 05)$.

* For details, see p. 190 and Table 1.

during the digestibility period of the experiment since no similar observation has been made in a subsequent experiment using the same four diets as used here but where diets were given ad lib. throughout.

The elevated faecal $\mathrm{N}$ excretion observed when birds were fed on diets containing tannins could have resulted from either higher levels of endogenous protein in faeces, impaired digestion of dietary protein, or both. The observation is consistent with many similar observations (Griffiths \& Moseley, 1980; Mohammed \& Ahmed, 1987) which clearly demonstrate the adverse effect of dietary tannins.

The pancreatic enlargement induced by the tannin-containing diets in this experiment may have been an adaptive growth response to the presence of tannins in the gut, probably 
mediated by hormones transported in the blood. Several investigators (Rothman \& Wells, 1967; Johnson \& Guthrie, 1974; Solomon et al. 1978; Dembinski \& Johnson, 1980) have demonstrated the roles of gastrointestinal hormones, particularly cholecystokinin (CCK) and secretin, on pancreatic growth. Pancreatic enlargement similar to that obtained in the present experiment has been reported previously in response to soya-bean trypsin inhibitor (Levison et al. 1979) and lectins (Abbey et al. 1979; Grant et al. 1987). This may indicate a common mode of action of these antinutritional substances, at least at a cellular level. Brand \& Morgan (1981) have demonstrated that oral administration of soya-bean trypsin inhibitor to the rat elicits a rapid fall in the concentration of CCK in gut tissue, probably as a result of secretion of CCK into the circulation; it is possible that tannins may exercise a similar influence.

Pancreatic synthesis and secretion is predominantly influenced by gastrointestinal hormones; CCK plays a major role by direct action on pancreatic acini (Rothman \& Wells, 1967; Mainz et al. 1973; Liddle et al. 1985). The presence of tannins in the diet, through their effect on enzymes in the gut, may augment the secretion of CCK. In chickens it is possible that there is an additional factor involved in the regulation of pancreatic function. In contrast to other simple-stomached animals, the nerve endings in the pancreas of the domestic fowl terminate in direct contact with the acinar cells (Watanabe \& Yasuda, 1977). This may indicate more involvement of neurocontrol in synthesis and secretion of pancreatic enzymes in the domestic fowl.

The ratio, $\alpha$-amylase:trypsin activity accumulated within the pancreas was higher for the treatment groups $(9 \cdot 7: 1$ average) than for the control birds $(7 \cdot 8: 1)$ and activities of both enzymes in pancreatic tissue were increased. This does not accord well with the effect of CCK on enzyme synthesis by rat pancreatic cells in vitro (Case et al. 1988) which resulted in a $42 \%$ increase in trypsinogen 1 and virtually no change in amylase synthesis $(-4 \%)$. On the other hand administration of CCK by injection to rats over a $9 \mathrm{~d}$ period resulted in both pancreatic hypertrophy and increased activities of $\alpha$-amylase and trypsin (Barrowman \& Mayston, 1974). In a series of experiments (A. E. Ahmed and R. Smithard, unpublished results) we have noted that responses in the activities of $\alpha$-amylase and trypsin in the pancreas to the presence of tannins in the diet may parallel one another or may differ quite markedly, depending on the period over which the birds have been fed on tannins.

At the highest level of dietary tannin the $\alpha$-amylase activity in the gut was restored whilst that of trypsin remained severely inhibited. In this group of birds it appears that the hypertrophied pancreas, which was able to accumulate the highest amount of $\alpha$-amylase, was able to secrete sufficient $\alpha$-amylase to combine with free tannins and to restore amylolytic activity to a normal level in the gut. Our recent unpublished work (A. E. Ahmed and $\mathrm{R}$. Smithard) has revealed the presence of high levels of trypsinogen but low trypsin activity in the intestinal chyme of birds fed on diets with high levels of tannins. Activation of this chyme with enteropeptidase resulted in 1.3-fold higher trypsin activity. It is therefore possible that mucosal enteropeptidase needed for the activation of trypsinogen, like the other mucosal enzymes assayed in the present experiment, is inhibited by tannins in the gut; also, tryptic autolysis may have been inhibited as found in vitro (Mole \& Waterman, 1985). It might be expected that inhibition of enteropeptidase, as the activator of trypsin, might have a more pronounced effect on proteolytic activity than direct tannin inhibition of trypsin itself.

The inhibition of brush-border enzymes observed in the present study may have resulted from either direct complex formation between the enzymes and the tannins or through secondary effects which led to diminished synthesis. There is a close association between membrane digestion and the absorption of nutrients and it is likely that the tannins exert an indirect effect on absorption through this association. It is also possible that the 
unabsorbed nutrients may affect osmoregulation of gut fluids, resulting in enhanced food passage (Launiala, 1968).

The findings reported here support the contention that the excessive excretion of faecal $\mathrm{N}$ associated with ingestion of tannins may largely be ascribed to the formation of tannin endogenous enzyme complexes which inhibit digestion of dietary protein. There is also the possibility that tannins may play a role in the absorption of nutrients and this aspect is at present under further examination.

\section{REFERENCES}

Abbey, B. W., Norton, G. \& Neale, R. J. (1979). Effect of dietary proteinase inhibitors from field bean (Vicia faba L.) and field bean meal on pancreatic function in rats. British Journal of Nutrition 41, 39-45.

Agricultural Development and Advisory Service (1986). Manual of Analytical Methods, pp. 168-169. London: H.M. Stationery Office.

Asquith, T. N. \& Butler, L. G. (1985). Use of dye-labelled protein as spectrophotometric assay for protein precipitants such as tannins. Journal of Chemical Ecology 11, 1535-1544.

Barrowman, J. A. \& Mayston, P. D. (1974). The trophic infiuence of eholecystokinin on the rat pancreas. Journal of Physiology 238, 73P.

Brand, S. J. \& Morgan, R. G. H. (1981). The release of rat intestinal cholecystokinin after oral trypsin inhibitor measured by bioassay. Journal of Physiology 319, 325-343.

Case, R. M., Musa, O. \& Padfield, P. J. (1988). Regulation of synthesis of individual secretory proteins by cholecystokinins and acetylcholine in rat pancreas in vitro. Journal of Physiology 403, 45P.

Dahlqvist, A. (1968). Assay of intestinal disaccharidase. Analytical Biochemistry 22, 99-107.

Dembinski, A. B. \& Johnson, L. R. (1980). Stimulation of pancreatic growth by secretin, caerulein and pentagastrin. Endocrinology 106, 323-327.

Fenton, T. W. \& Fenton, M. (1979). An improved method for chromic oxide determination in feed and faeces. Canadian Journal of Animal Science 59, 631-634.

Gertler, A. \& Nitsan, Z. (1970). The effect of trypsin inhibitors on pancreatopeptidase E, trypsin, chymotrypsin and amylase in the pancreas and intestinal tract of chicks receiving raw and heated soya bean diets. British Journal of Nutrition 24, 893-904.

Grant, G., Wat, W. B., Stewart, J. C. S. \& Pusztai, A. (1987). Effect of dietary soya bean (Glycine max) lectin and trypsin inhibitors upon the pancreas of the rat. Medical Science Research 15, 1197-1198.

Griffiths, D. W. (1981). The polyphenolic content and enzyme inhibiting activity of testas from bean (Vicia faba) and pea (Pisum spp.) varieties., Journal of the Science of Food and Agriculture 32, 797-804.

Griffiths, D. W. \& Moseley. G. (1980). Effect of diet containing field beans of high and low polyphenolic content on the activity of digestive enzymes in the intestine of rats. Journal of the Science of Food and Agriculture 31, $255-259$.

Hagerman, A. E. \& Butler, L. G. (1980). Determination of protein in tannin-protein precipitate. Journal of Agricultural Chemistry 28, 952-957.

Hagerman, A. E. \& Klucher, K. M. (1986). Tannin protein interaction. In Flavanoids in Biology and Medicine. Biochemical, Pharmacological and Structure-Activity Relationships, pp. 67-76 [J. Harbourne and E. Middeton, editors]. New York: Alan R. Liss.

Hamerstrand, G. E., Black, L. T. \& Glover, J. D. (1981). Trypsin inhibitor in soy products: modification of the standard analytical procedure. Cereal Chemistry 58, 42-45.

Horigome, T., Kumar, R.\& Okamoto, K. (1988). Effect of condensed tannins prepared from leaves of fodder plants on digestive enzymes in vitro and in the intestine of rats. British Journal of Nutrition 60, 275-285.

Johnson, L. R. \& Guthrie, O. D. (1974). Effect of CCK and 16,16-dimethyl PGE on RNA and DNA of gastric and duodenal mucosa. Gastroenterology 70, 59-65.

Kotb, A. R. \& Luckly, T. D. (1972). Markers in nutrition. Nutrition Abstracts and Reviews 42, 813-845.

Lasheras, B., Cenarruzabeitia, M. N., Fontan, J., Lluch, M. \& Larralde, J. (1980). Effect of raw legume diets on disaccharidase activity in the small intestine of chicks. Revistas Española de Fisiologia 36, 331-336.

Launiala, K. (1968). Effect of unabsorbed sucrose and mannitol on the intestinal flow and mean transit time. Scandinavian Journal of Gastroenterology 3, 665-671.

Levison, D. A., Morgan, R. G. H., Brimacombe, J. S., Hopwood, D., Coghill, G. \& Wormsley, K. G. (1979). Carcinogenic effects of di-(2-hydroxypropyl)-nitrosamine (DHPN) in male Wistar rats: promotion of pancreatic cancer by a raw soya flour diet. Scandinavian Journal of Gastroenterology 14, 217- 224.

Liddle, R. A., Godfine, I. D., Rosen, M. S., Taplitz, R. A. \& Williams, J. A. (I985). CCK bioactivity in human plasma. Journal of Clinical Investigation 75, 1144-1152.

Lumen, B. O. \& Salamat, L. A. (1980). Trypsin inhibitor activity in winged beans and possible role of tannins. Journal of Agricultural and Food Chemistry 28, 353-365.

Mainz, D. L., Black, O. \& Webster, P. D. (1973). Hormonal control of pancreatic growth. Journal of Clinical Investigation 52, 2300-2304. 
Makker, H. P. S., Singh, B. \& Dawra, R. K. (1987). Tannin-nutrients interaction - a review. International Journal of Animal Science 2, 127-140.

Martin, J. S., Martin, M. M. \& Bernays, E. A. (1987). Failure of tannic acid to inhibit digestion or reduce digestibility of plant protein in gut fuids of insect herbivores. Journal of Chemical Ecology 13, 605-621.

Martin, M. M., Rocholum, D. C. \& Martin, J. S. (1985). Effect of surfactants, pH and certain cations on the precipitation of protein by tannins. Journal of Chemical Ecology 11, 485-494.

Miller, D. \& Grane, R. K. (1961). The digestive function of the epithelium of small intestine. I - an intracellular locus of disaccharide and sugar phosphate ester hydrolysis. Biochimica et Biophysica Acta 52, 281-293.

Mitjavilla, S., Lacombe, C., Carrera, G. \& Derache, R. (1977). Effect of tannic acid and oxidised tannic acid on the functional state of rat intestinal epithelium. Journal of Nutrition 107, 2113-2121.

Mohammed, T. A. \& Ahmed, A. E. (1987). Feeding and metabolic studies on the nutritive value of grain sorghums with reference to their tannin content. Sudan Journal of Veterinary Science and Animal Husbandry $\mathbf{2 6}$, 91-101

Mole, S. \& Waterman, P. G. (1985). Stimulatory effect of tannins cholic acid on tryptic hydrolysis of protein. Journal of Chemical Ecology 11, $1323-1332$.

Mole, S. \& Waterman, P. G. (1987). Tannic acid and proteolytic enzymes: enzyme inhibition or substrate deprivation. Phytochemistry 26, 99102.

Nicholson, J. A. \& Kim, Y.S. (1975). A one step L-amino acid oxidase assay for intestinal peptide hydrolysis activity. Analytical Biochemistry 63, 100-117.

Price, M. L., Scoyoc, S. V. \& Butler, L. G. (1978). Critical evaluation of vanillin reaction as an assay for tannin in sorghum grain. Journal of Agricultural and Food Chemistry 26, 1214-1218.

Rothman, S. S. \& Wells, H. (1967). Enhancement of pancreatic growth by pancreozymin. American Joumal of Physiology 213, 215-218.

Sarkar, S. K. \& Howarth, R. E. (1976). Specificity of vanillin test for flavanols. Journal of Agricultural and Food Chemistry 24, 317-320.

Solomon, T. E., Peterson, H., Elashaff, J. \& Grossman, M. I. (I978). Interaction of caerulein and secretin on pancreatic size and composition in the rat. American Journal of Physiology 235E, 714719.

Terpstra, K. \& De Hart, N. (1974). The estimation of urinary nitrogen and faecal nitrogen in poultry excreta. Zeitschrift für Tierphysiologie, Tierernährung und Futtermittelkunde 32, 306-320.

Watanabe, T. \& Yasuda, M. (1977). Electron microscopic study of the pancreas of the domestic fowl. Cell Tissue Research 180, 453-465. 